\title{
MANAGEMENT OF 20TH CENTURY HYDROELECTRIC PLANTS AS INDUSTRIAL HERITAGE
}

\author{
N. Kuban ${ }^{1,}$, İ. T. Güven ${ }^{1}$, M. Pretelli ${ }^{2}$ \\ ${ }^{1}$ KOU, Faculty of Architecture and Design, 41300 İzmit Kocaeli, Turkey - nnkuban@ gmail.com, nurdan.kuban@kocaeli.edu.tr, \\ guvenit@kocaeli.edu.tr \\ ${ }^{2}$ UNIBO, Dipartimento di Architettura 47522 Cesena, Italy - marco.pretelli@unibo.it
}

KEY WORDS: Hydroelectric Plant, Gravity Dam, Architectural Conservation, Planned Conservation, Preventive Measures

\begin{abstract}
:
By rapidly increasing the production of energy and widely extending the usage of electricity in the 20th century, hydroelectric plants and dams have radically affected the social, technological and industrial aspects of the period. Therefore, as an integral part of industrial heritage, the cultural assets of these energy facilities are required to be preserved. As a requirement of this hypothesis, it is necessary: to develop management strategies for these assets; to provide scientific data and information on these buildings / facilities; to define criteria of 'planned conservation' with long-term preventive measures in order to provide the continuation of the original function as long as possible. Hydroelectric plants are a common subject of interest for several disciplines, such as: engineering, hydrology, ecology, geo-sciences and remote sensing. Therefore, the conservation of the plants also requires the interdisciplinary study and collaboration of these disciplines.

Within the study, the considerations of an interdisciplinary approach -such as dam safety, ecological concerns and energy requirements- are presented, and examples from different countries are examined through the framework of architectural conservation, considering cases of dam failures, intended removal of dams and upgrading of facilities. Preventive measures for the planned conservation of hydro electrical facilities such as: constant maintenance of technical components; management of the sediment accumulated in the reservoirs; methods of analysis for the structure of the embankment are introduced briefly, concentrating on gravity dams, in order to provide conclusions for the conservation of Sariyar Dam and Hydroelectric Plant (1956) in Turkey.
\end{abstract}

\section{INTRODUCTION}

"In the past, in contrast to modern times, the manner of building, materials, structural systems, and forms of ornaments were related to particular cultures, and only changed over long periods of time, thus giving a certain harmony and continuity to a place" (Jokilehto, 2011). However, in the rapidly changing modern era, "the control of change and the regeneration of values have taken an important role with the preservation of physical remains" (Jokilehto, 2011).

Conservation of architectural heritage aims to control and monitor the process of change; however, -in spite of the connotations attached to it- the contemporary approach of conservation does not seek to prevent or stop the natural change or evolution of cultural assets. As Venice Charter suggests: "The valid contributions of all periods to the building of a monument must be respected, since unity of style is not the aim of a restoration." When a building includes the superimposed work of different periods accumulated over a long period of time, the traces of various periods must be taken into consideration. Venice Charter brings up the issue of variations in the architectural styles which evolve slowly in long periods of time. However, monitoring of changes in modern assets of cultural heritage is generally more difficult to manage, because of the rapid changes in construction techniques, materials and approaches. Buildings of cultural value need to be utilized and the continuation of function needs to be provided in order to secure the sustainability of the structure and the values of the heritage. However, the continuation of function is challenging in some cases -especially when industrial heritage is considered-, since rapid improvements in technology threaten the 'out-dated' buildings and structures of heritage. Preventive measures for possible risks, continuous maintenance and monitoring are required in order to provide the longer life aimed for such structures, while assuring the sustainability of environmental and cultural features. Therefore, a thorough evaluation of industrial, structural, environmental and cultural criteria and a balance of various disciplines need to be constituted in order to provide the management of industrial heritage.

By rapidly increasing the production of energy and widely extending the usage of electricity in the 20th century, hydroelectric plants and dams have radically affected the social, technological and industrial aspects of the period. Therefore, as an integral part of industrial heritage, the cultural assets of these energy facilities are required to be preserved. As a requirement of this hypothesis, it is necessary: to develop management strategies for these assets; to provide scientific data and information on these buildings / facilities; to define criteria of 'planned conservation' with long-term preventive measures in order to provide the continuation of the original function as long as possible.

Interdisciplinary preventive measures for the sustainability of dams and hydroelectric facilities require the consideration of three main issues: dam safety for human-life, arrangements for

\footnotetext{
* Corresponding author
} 
ecological concerns, and sustainability / upgrading at the facilities of industrial heritage. Therefore, within the study, examples of hydro electrical plants from various countries are examined through the framework of architectural conservation, considering cases of 'dam failures,' 'intentional removal of dams' and 'upgrading of facilities with awareness of cultural features.' Preventive measures for the planned conservation of hydro electrical facilities such as: constant maintenance of technical components; management of the sediment accumulated in the reservoirs; methods of analysis for the structure of the embankment are introduced briefly, concentrating on gravity dams, in order to provide conclusions for the conservation of Sariyar Dam and Hydroelectric Plant (1956) in Turkey.

\section{CONSIDERATIONS AND PREVENTIVE MEASURES FOR CONCRETE GRAVITY DAMS}

Powers of nature have always been utilized as sources of energy since the beginning of human settlements, as in the case of hydraulic mills for grinding grains. After the invention of methods for making use of electricity in the $19^{\text {th }}$ century, the combination of studies on hydraulics and electrical engineering resulted in the development of hydroelectric plants for the production of electricity. The initial motive for constructing hydroelectric facilities had been the requirement of energy. However, after about one-hundred years of existence, the hydroelectric facilities of the $20^{\text {th }}$ century have become subjects to the concerns of various disciplines such as engineering, ecology, heritage preservation and tourism. In compliance with the interdisciplinary nature of the subject, considerations of various disciplines regarding concrete gravity dams are categorized as: dam-safety, ecological aspects, and energy requirements, and the categorized aspects are examined through the preventive measures for the conservation of hydroelectric facilities as an integral component of cultural heritage.

\subsection{Dam Safety}

Although disasters caused by dam failures are comparatively rare, they cause large-scale loss of lives, and the flooding of settlements. Therefore, dam safety has always been a crucial issue since the construction of the first dams. There have been several discussions on issues of dam safety such as: deterioration by aging, distortion / deformation, piping, problems related to sedimentation, settlement due to earthquakes, floods, etc. (ICOLD, 2018). However, the process of theorizing the field dates back to 1987 when ICOLD (International Commission on Large Dams) published the "Dam Safety Guidelines." It is a traditional 'standards-based' document, meaning that it specifies standards for the safety of dams. The introduction of 'risk analysis' into the practice of dam safety dates much later: to the mid 1990's, when the approach of risk assessment started to be applied in some of the leading countries. ICOLD published "Risk Assessment in Dam Safety Management" in 2005 as an introduction to the principles and terminology of risk assessment. Risk assessment provides the precise specification and a thorough understanding of potential failures of a dam. However a risk analysis secluded from the standards-based approach is also not favoured. Therefore, a 'risk-informed' approach is preferably adopted which incorporates and adapts the 'standards-based' approach along with a deep investigation of a 'risk-analysis' (Bowles, 2018).
Dam failures are caused either by exceptional circumstances, such as floods, upstream dam-break waves, earthquakes and war, or they may occur in normal circumstances, such as first filling, aging and internal erosion or construction accidents (Slunga, 2001). In any case, safety of dams and hydroelectric plants require the careful analysis, maintenance and monitoring of the embankment, the reservoir and the machinery / equipment throughout the entire life of the facilities. Moreover, the geology and topography of the surrounding site must also be examined thoroughly and periodically, with special attention to changing climatic and environmental conditions.

Water is generally involved in the forms of deterioration of concrete in dams, and the rate of deterioration is often related to the degree of permeability. Physical effects that adversely affect the durability of concrete include: surface wear, cracking due to salt, and exposure to temperature extremes such as fire or frost. Deleterious chemical effects include: leaching of cement paste by acidic solutions, sulphate attack, alkali-aggregate reactions and corrosion of embedded steel (Charlwood, 2009). Such effects must be considered and eliminated during the design and construction of the dam, and careful maintenance must be provided. However, the monitoring of facilities is made more difficult by changing external criteria such as floods, earthquakes and landslides. Stability analyses of dam structures are necessary to monitor the facilities under: dead loads, external water imposed loads, internal (hydrostatic and hydrodynamic) loads, earth and silt pressures, earthquake forces, and ice loads (FERC, 2018). FERC (Federal Energy Regulatory Commission of USA) categorizes the methods of analysis for concrete gravity dams as: Gravity Method (the initial and basic analysis where the dam is assumed to be a twodimensional rigid block, and the foundation pressure distribution is assumed to be linear), Finite Element Methods (a method for dams with irregular geometries, where the actual geometry of the structure and the foundation rock below the dam are modelled), Dynamic Methods (analysis of loads whose duration is short, such as seismic, blast and impact), and Cracked Base Analysis (FERC, 2018).

Deteriorations, deformations and displacements on the embankments of hydroelectric facilities must be observed, measured and monitored in order to prevent any possible damages. Measurement devices and techniques in metrological monitoring of dams are mainly based on the monitoring of discrete points. Besides photogrammetric techniques, for the recording of surfaces, nowadays laser scanners are used, which acquire dense point clouds in a very short time (Schneider, 2006). Several studies discuss the use of TLS (Terrestrial Laser Scanning) for the monitoring of deformations on dams (Tschirschwitz et. al., 2016; Antova, 2015, Alba et. al., 2006) where the surface of the dam is divided in small homogeneous areas and for each of these areas, an interpolating surface is estimated. Because different point clouds have been already geo-referenced into the same reference system, the comparison between interpolated surfaces allows the evaluation of displacements (Alba et. al., 2006). Any deformation or displacement observed on the embankment requires immediate measures in order to prevent dam failures.

Besides the embankment, the reservoirs also require periodic maintenance and inspection. The accumulation of sediment in reservoirs behind the embankments decreases the energy production of plants along with the aging of the dam, causing severe consequences for water management, flood control and energy production. Measures must be taken for the reduction of 
incoming sediment; minimization of sediment deposition and removal of sediment from reservoirs (Suneel, 2018). Sediments can be trapped upstream of dams by construction of structures upstream, by providing vegetation filters, by providing sediment detention basins, by providing reservoir off-stream for sediment removal or by construction of wetlands (Suneel, 2018). Removal of the accumulated sediment is possible through flushing or dredging (Suneel, 2018).

Detailed analysis and modelling of the surroundings and the natural structure is also important for the safety of dams. In recent years, numerical models have been increasingly used to understand complex flows, sediment transport and the corresponding morphological changes in rivers, floodplains, hydrological / ecological and geomorphological conditions of catchments (Guan et. al., 2018). Besides, several recent studies use shallow water numerical models in order to simulate dambreaks (Guan et. al., 2018; Pilotti et. al., 2011; Bosa and Petti, 2011).

Collapse of a dam, not only results in the loss of the hydroelectric facility as industrial heritage, but also causes disastrous effects on the lives of the people, the urban or rural settlements and the ecological habitat in the surrounding area. Therefore, the initial concerns in means of the conservation of the hydroelectric plants are the preventive measures to be taken for dam safety. A risk-informed approach must be adopted for the control and monitoring of hydroelectric plants; continuous maintenance of facilities must be provided; scientific inspection and observation must be carried out at and around the site in order to detect any unexpected changes.

\subsection{Ecological Aspects}

In case of 'storage hydroelectric plants,' dams are constructed, storing the water of flowing rivers and creating a reservoir lake, to increase hydraulic head in order to convert the power of the water into electricity. Such plants are giant machine-like structures in the body of nature, drastically changing the physical, climatic and ecological conditions of the surrounding sites. The impacts of such an intervention in nature include habitat alteration of rivers, loss of floodplains and wetlands, deterioration and loss of river deltas and dewatering of rivers. In some cases, dams interrupt migratory routes of fish and they affect the abundance of such species.

Because of these reasons, since 1990s, especially in the USA, dam removal has increasingly become a legitimate tool for restoring rivers and aquatic ecosystems (McClain et. al., 2008). Most of the dams removed are less than 10 meters in height, but there are cases where large dams over 30 meters are also removed (Germaine and Lespez, 2017). Removal can be a solution to problems of unsafe infrastructure and it can stimulate waterfront revitalization, possibly providing new recreation opportunities and economic development. Removals can allow migratory fish species access to historic spawning grounds, improving water quality and the natural movement of sediment and other nutrients by reestablishing natural flow regime (McClain et. al., 2008).

However, there is a possibility that efforts of dam removal concentrating on 'Nature in its purest form preserved from Man's domination' (Rodriguez, 2012) may not be accomplished. Bellmore et. al. (2019) suggest that "rivers, given the opportunity, can indeed recover substantially from having been dammed, but the structure and function of the ecosystem may not be the same or even similar to what existed prior to dam emplacement. (...) The ecological communities that assemble following dam removal may be very different than those that existed before the dam was constructed. Moreover, baseline conditions of the watershed may have changed significantly while the dam was in place. (...) The ability to go back to a pre-dammed state will likely depend on how long the dam existed and the magnitude of its many-faceted effects on the ecosystem" (Bellmore et. al., 2019). Therefore, removal of the dam can create a second major intervention in nature, interrupting the new equilibrium balanced by nature in the long presence of the dam constructed. There are risks of flooding and landslides after the removal of a dam in cases where the necessary preventive measures are not taken. Besides the loss of the hydroelectric facility, such incidents can also threaten urban or rural settlements and monumental assets of cultural heritage in the vicinity of the project.

Therefore, experts on issues of ecology, engineering and heritage conservation should conduct scientific collaborations on whether the removal of a certain dam could adversely affect the ecological and cultural environment, and methods should be specified for avoiding, minimizing and mitigating such adverse effects.

If the removal of a dam could create adverse effects, less radical interventions for ecological concerns should be preferred. In cases where dams interrupt migratory routes of fish, 'Fish Passes (fish ladders)' can be constructed with the objective of mitigating this impact, reestablishing connectivity between habitats critical to the maintenance of the fishery stocks and to the conservation of species diversity (Agostinho et.al., 2007). Such solutions would enhance the efforts of ecological concerns without endangering the physical and cultural environment.

\subsection{Energy Requirements}

Since the industrial revolution, the requirement for energy continues increasingly, necessitating the upgrading of energy plants. Upgrading and addition of new technologies are sometimes inevitable for the survival of the 20th century plants, as they enable the continuation of the original function. Interventions such as addition of new turbines, generating units, penstocks and machinery can even be perceived as the contributions of the changing technology to the industrial heritage. However, attention must be paid not to lose the original properties of the heritage through a fierce and overwhelming upgrading process. After almost a century, hydroelectric facilities have become a part of industrial heritage, and -unlike the initial phases of construction- energy production is not the only consideration for their evaluation anymore; they have gained cultural value and they are subject to the interest of industrial tourism. Therefore, the change and expansion of the facilities must be monitored; addition of new elements and upgrading of the systems must prioritize the original elements and features. The original machinery and components must be well maintained and preserved for the continuation of function, and in cases when the original elements are not possible or sustainable to use, they must be repaired and exhibited at the site or in the vicinity, open to the public, for the interest of industrial heritage. 


\section{MANAGEMENT OF HYDRO ELECTRIC FACILITIES IN VARIOUS CASES}

In accordance with the considerations and preventive measures discussed, various cases of concrete gravity dams and hydroelectric facilities are examined within the study, through the framework of architectural conservation under categories of: dam failures, intentional removal of dams and upgrading of facilities with cultural properties.

\subsection{Dam Failures}

Gleno Hydroelectric Plant, with an installed capacity of 3.7 MW, was constructed on Gleno Creek in Italy between 1916 and 1923. The initial project of the dam was designed as a concrete gravity dam, but after the construction of the foundations for the concrete gravity dam, with a change of plans, a multiple-arch concrete dam was constructed with a height of 43 meters, and a length of 200 meters. The change in the type of dam and the use of poor materials and techniques in the construction caused the failure of the dam flooding the settlements of Bueggio, Dezzo, Azzone, Colere and Corna di Darfo, killing at least 356 people on December 1, 1923 (Figure 1). The failure of Gleno Dam accelerated the studies on dam safety in Italy in the 20th century. The failed dam of Gleno still constitutes the subject of scientific studies testing the methods for dam safety. Pilotti et. al., in their study on the Gleno Dam, reconstructed the event by recovering a great deal of information that can be used for modelling purposes. Since topography surveys of the site were not available for the area before 1923 -and the flood has severely changed the previous topography- they had to reproduce the bathymetry by means of a 5 x 5 digital elevation model (DEM) based on historical documents and they prepared a two-dimensional (2D) shallow water simulation describing the dynamics of the reservoir emptying and a one-dimensional (1D) modelling of the dam break wave propagation, with a first-order finite volume numerical scheme (Pilotti et. al., 2011). The remains of the failed dam are still at the site open to the interest of the public. Besides, in memory of the disaster, a collection of documents, photographs and testimonies of the industrialization in 1920s is exhibited at the "Gleno Exhibition Space."
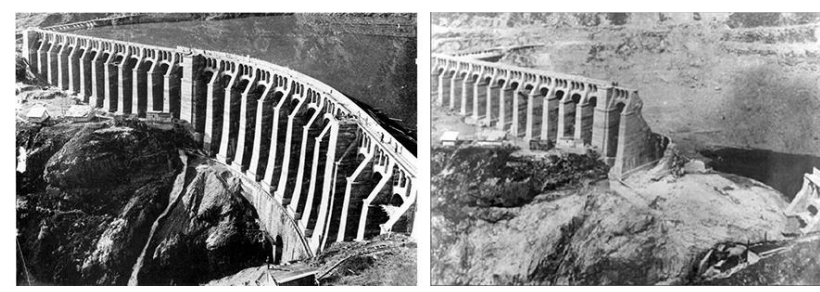

Figure 1. Gleno Dam before and after the collapse (Luino et. al., 2014)

Vajont Dam, a concrete arch dam constructed on Vajont River between 1957 and 1959, was a structure with a height of 262 meters, a length ranging between 27 meters (at the base) - 191 meters (at the top) and thickness of 22.11 meters (at the base) 2.4 meters (at the top). It was designed by Carlo Semenza and constructed by Società Adriatica di Elettricità ("SADE", or "EDIS") (English: Adriatic Energy Corporation). In 1962, the dam was nationalized to be run by ENEL as part of the Italian Ministry for Public Works. However, three years after the filling of the basin, on October 9, 1963 a landslide occurred at the site destroying Longarone, causing about 2000 causalities and complete devastation. The extraordinary aspect of the Vajont case is that: it is not exactly a dam failure, as the structure of the concrete dam still remains intact at the site. The dam did not collapse, but huge masses of earth and rocks fell into the reservoir as a result of a landslide upstream, and the water in the reservoir overtopped the dam causing the disaster (Figure 2).

Landslides had already been occurring at the site before the construction of the dam, and the operators at the facilities were lowering the level of the reservoir accordingly. However, they had not expected a landslide with such a huge impact. The water in the reservoir caused the loosening in the base of the mountains -increasing the impact of the landslide. The case proves that within the design and monitoring of such structures, the work is not limited to the studies on the dam construction itself. Detailed studies and monitoring must also be carried out about the surroundings and the changing conditions. The Vajont Disaster still constitutes a subject of many scientific studies for shallow water numerical modeling (Bosa and Petti, 2013), 3D SPH numerical stimulation (Vacondio et. al., 2013) and slope stability (Paronuzzi et. al, 2013).

For the past 20 years, The Vajont Dam has become a place to visit, open to the public, and it is currently managed by the Friulian Dolomites Park. Hosting over 100,000 visitors annually, the site presents two routes to follow: a short 40minute visit and a longer 3-hour visit. Volunteers serve at the site as "informers of memory", who tell of the valley's history, its community, the dam and the disaster.
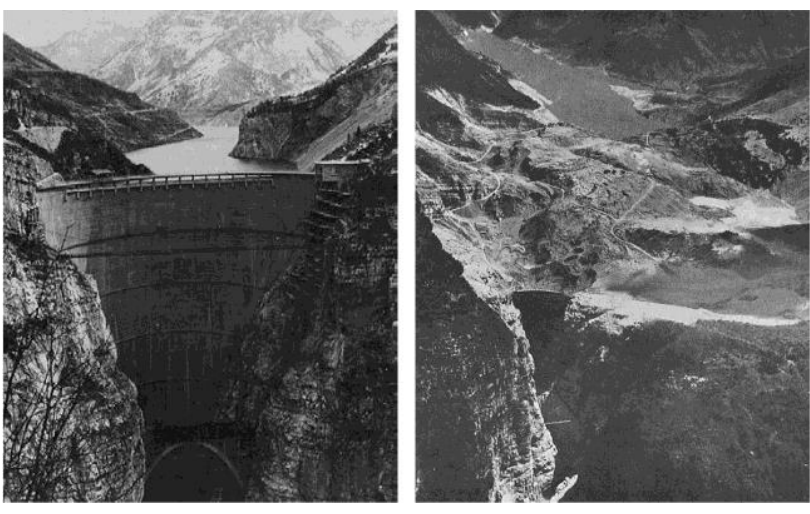

Figure 2. Vajont Dam before and after the landslide (Runout, 2000)

\subsection{Intentional Removal of Dams}

Elwha Dam, on the Elwha River in the United States, was constructed by L. L. Summers of Chicago between 1911 and 1914. The 33 meter high embankment consisted of a 120 foot long concrete gravity central section flanked by concrete multiple-buttress spillway and intake sections. During the construction, in 1912, a leakage occurred; the dam and the powerhouse with the generating units and the switchboard was severely damaged. However, the top part of the dam was still intact after the leakage, like a bridge wedged between the walls of the canyon. In reconstructing the dam, excavated materials from the walls of the canyon were placed as a heavy rock-fill above, below and beneath the dam. By December 1914, the construction of the dam was completed after the reconstruction. The installed capacity of the plant was $14.8 \mathrm{MW}$ with 4,800 hp Wellman Seaver Morgan Francis type, double runner turbines. The powerhouse was a two-storey concrete building resting on a bedrock and structurally supported by reinforced concrete columns faced with curtain walls. The generating units were on 
the ground floor, and transformers and switching apparatus were on the first floor.

In 1921-1922, two new generators were added to the plant and extensions were made at the powerhouse. The Elwha River Plant was purchased by the Crown Zellerbach Corporation in 1937. On December 15, 1988 the power plant was registered in National Register of Historic Places.

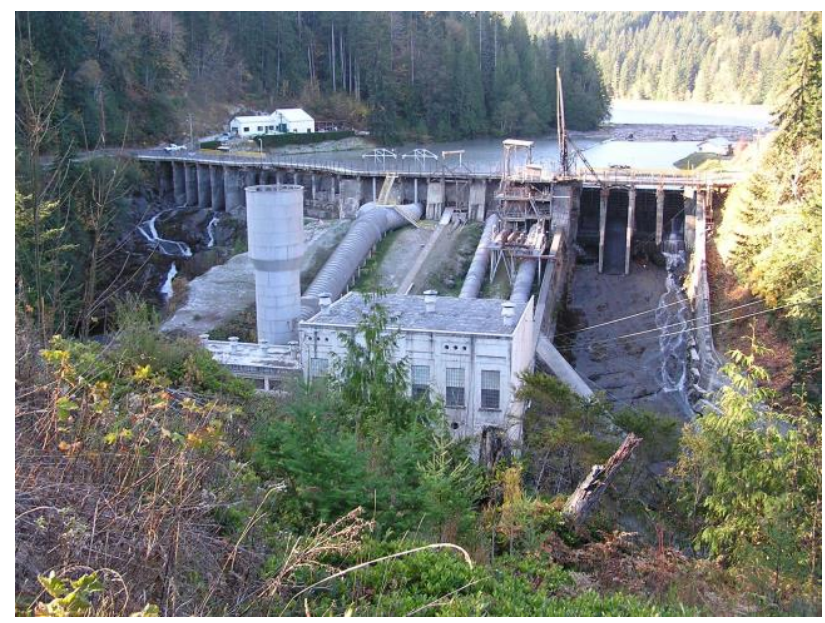

Figure 3. Elwha Dam before removal (Ward, 2005)

The report for the register of the facilities state that: "The Elwha River Hydroelectric Power Plant is a historically significant example of a low head hydroelectric system in Washington State from the early 20th century. In addition, the dam is a rare, early example of the multiple-buttress type. Finally, the "blowout", and reconstruction, of the original dam foundation is noteworthy because it represents a failure of early engineering and a successful response to that failure. Although some changes have been made to the system over the years, no one element has been so altered that the continuity of the system is compromised" (Soderberg, 1986).

However, for the restoration of the habitat at the site, the removal of the dam was initiated in September 2011 and it was completed in March 2012, including the demolishment of the dam, water conveyance system and powerhouse all of which had been registered as cultural heritage. A detailed report was prepared before the removal of the dam, which discusses and explains measures for the impact of the removal on cultural resources. According to the report, "cultural resources include: structures, landscapes, traditional cultural properties, archaeological sites, ethno-historic sites, and contemporary resources such as fish and cedar used for cultural purposes. The historic resources of the area include structures at the Elwha Ranger Station Historic District, a bridge, the hydroelectric projects themselves, and others" (National Park Service, 1996). To address the cultural requirements, "the National Park Service, Lower Elwha Klallam Tribe, Washington State Preservation Officer, and Advisory Council on Historic Preservation entered a programmatic agreement detailing the steps required for mitigation. The mitigation agreement specified that the NPS would oversee the survey and documentation of all historic structures, and develop an interpretive plan that would ensure that the story of Elwha and Glines Canyon dams would be conveyed effectively to park visitors and the general public. This historical narrative is part of that interpretive effort" (National Park Service, 1996).
According to an article published in 2011 on the local Newspaper Peninsula Daily News: 'Inside the control room, dam operator Paul Wesley monitors antique gauges juxtaposed with high-tech equipment. "It's kind of a blend of the modern and the old," Wesley said. "She is going on 100 years old, and most of what you see is original equipment. "These switches, gauges - some of these gauges here have patent dates in the 1800 s. Some of this equipment will be going to museums." (Ollikainen, 2011).

\subsection{Upgrading of Facilities with Cultural Properties}

Ruskin Dam on State River in Canada is a concrete gravity dam inaugurated in November 1930 (Figure 4). It is 59.4 meters in height and 110 meters in length. The installed capacity of the hydroelectric plant is $105 \mathrm{MW}$ with an annual generation of 374 GWh using three $35 \mathrm{MW}$ turbines of Francis type. The powerhouse is an Art-Deco building immediately adjacent on the river's eastern bank. Hydro-works in the valley was initiated by Western Canada Power Company, but after the provincial government took over the BC Electric Company, the facility has become the property of BC Hydro.

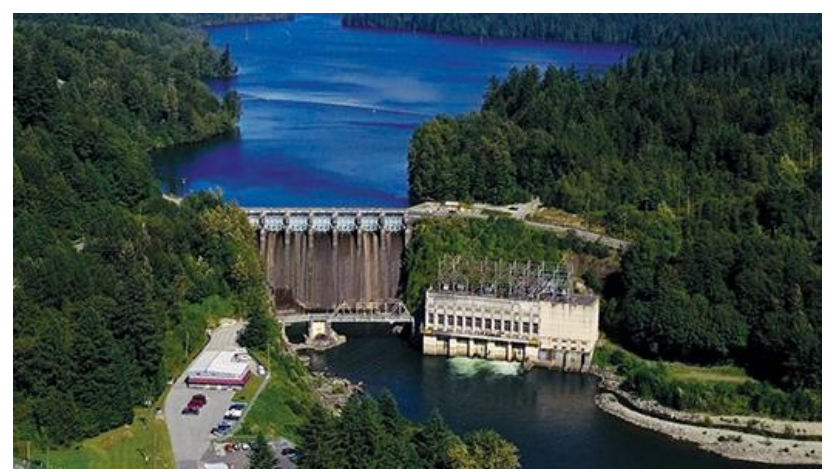

Figure 4. Ruskin Hydroelectric Plant (BCHydro, 2019)

Since 2012, the power plant is being upgraded, including the works of: seismic upgrades of the right bank (completed in 2013), seismic upgrades of the powerhouse (completed in 2013), dam upgrades -including new piers and spillway gates(completed in 2018), replacement of powerhouse equipment (completed in 2018), relocation of the switchyard (completed in 2017), upgrading of turbines and generators (completed in 2018), installation of new control room equipment (completed in 2018). The upgrading of the plant is still continuing, aiming for the works of: restoring trails including the Hairsine Inlet floating bridge, restoring 2-way traffic on Wilson Street at the dam, construction of a new 2-lane road over dam and the restoration of recreation sites. The upgrading project is scheduled to be completed by the spring of 2019. During the upgrading works, the Art-Deco power house and the elements of industrial heritage are being considered. A visitor center and recreation sites are among the aims of the upgrading project. The facility still contains a light bulb that has worked since the plant started operation in 1930.

\section{CONCLUSIONS AND CONSIDERATIONS FOR THE EVALUATION OF SARIYAR DAM IN TURKEY}

This study, exploring various aspects in the architectural conservation of 20th century hydroelectric plants, aims to emphasize that science is an interdisciplinary study. Construction of hydroelectric plants is subject to the common 
interests of geo-scientists, civil engineers, ecologists, electrical engineers and hydrologists. However, in the case of plants constructed in the past century, the evaluation of the structure is extended by the addition of a new property: cultural heritage value. Therefore, the discipline of heritage conservation is also included in the consideration of such properties.

The discussion of the study does not include the construction of new hydroelectric plants; it rather aims to explore methods to evaluate and conserve the cultural heritage properties of the plants built in the past century. Through enhancing and increasing the production of electricity, hydroelectric plants have extensively contributed to the industrialization and modernization of life in the 20th century. Evidently, not all of the plants can be preserved for future generations, but criteria must be specified to determine the evaluation of such plants in terms of industrial heritage. For those hydroelectric plants accepted as heritage, special conditions must be provided. With the awareness of the considerations of all the aforesaid disciplines, architectural conservation of these structures should prioritize the monitoring and management of the facilities in terms of their cultural properties. Monitoring and management should provide collaboration with geoscientists, civil engineers and hydrologists on the safety and the maintenance of the structures; collaborations should be established with ecologists for the specification and consideration of cultural and environmental priorities. Consultations with electrical engineers and civil engineers should be conducted in order to decide on the appropriate measures in the upgrading of facilities with the awareness of cultural features.

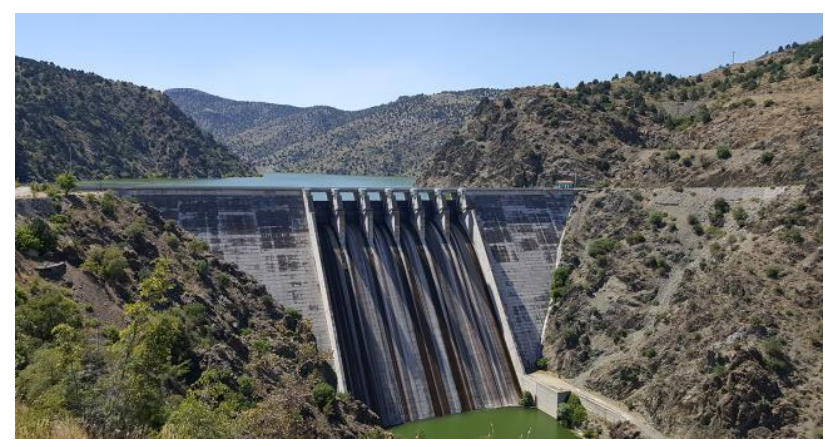

Figure 5. Sarıar Dam

As a conclusion of this study, the case in Turkey is mentioned briefly, and deriving from the studies discussed, preventive measures for the conservation of Sariyar Dam and Hydroelectric Plant are presented. The production and usage of electricity had been indispensable for the modern life of the 20th century. Hence, Turkish Republic -within the modernization attemptsalso initiated intense efforts for the production and distribution of electricity to every part of the country. Through the widespread of the electricity usage in Turkey, transformation has been threefold: the lighting of the streets became easier; modernization of social life was initiated as contemporary devices such as radio, iron, refrigerator, washing machine, electric grill etc. started to be used in each house; energy was sustained for several industrial plants (Erdem, 1963 and Dağaşan, 1963). The common usage of electricity has enabled an important development also in the transportation system; beginning with 1950's railroad transportation has incrementally evolved from a steam system to an electrical network (Baykara, 1955). Since energy is the primary requirement of industry, energy plants have been among the largest investments of Turkey in 1950's when the country was aiming an industrial breakthrough and a social transformation. Energy plants, established and developed in that period, have enabled Turkey to go through important transformations in terms of industry, transportation and social life, and therefore, they became important elements creating and reflecting the character and properties of the period.

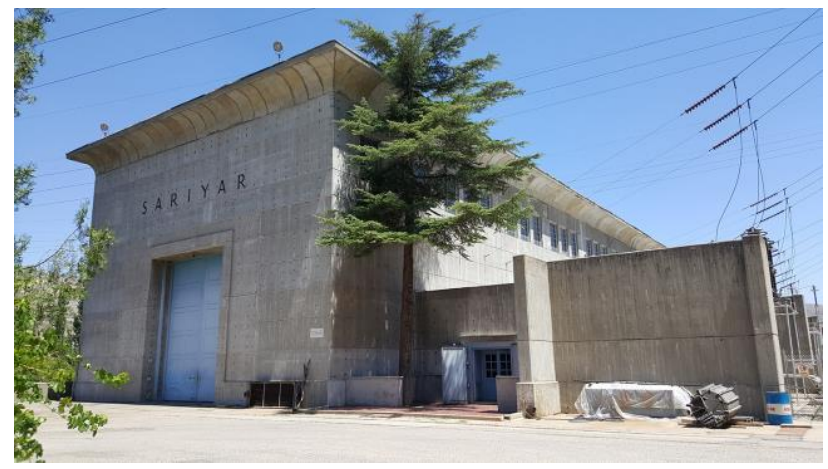

Figure 6. Sarlyar Powerhouse

Sarlyar Hydroelectric Plant was constructed in 1956 on Sakarya River in Turkey. The dam is a concrete gravity dam with a height of 90 meters and a length of 554 meters (Figure 5). The installed capacity of the plant is $160 \mathrm{MW}$ with an annual generation of $400 \mathrm{GWh}$ using four $40 \mathrm{MW}$ Francis type turbines (Figures 6-7).

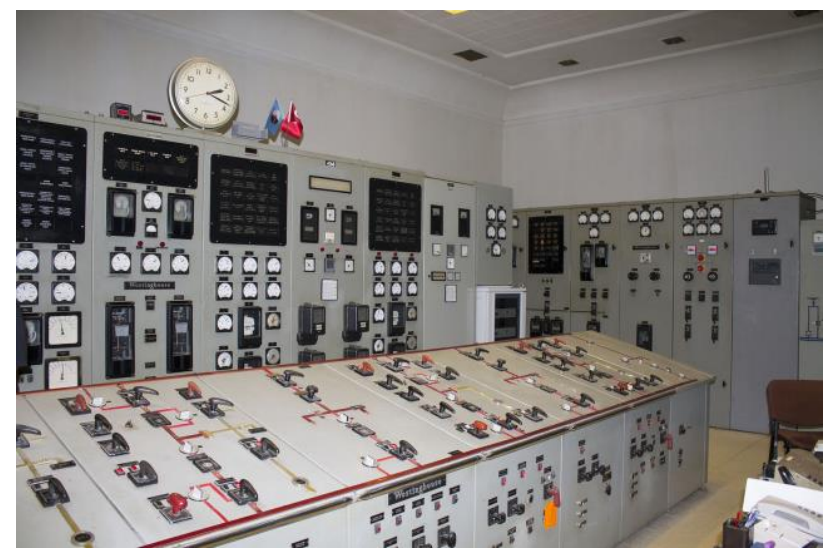

Figure 6. Sariyar Hydroelectric Plant, control room

It is one of the early attempts of hydroelectric power generation in the country. It is still producing electricity, but after 63 years, it is theoretically approaching the end of its productive life. Therefore, preventive measures must be taken for the sustainability and the conservation of the plant in the future. Upmost care and attention must be paid for any deterioration or unexpected change in the structure and the surroundings of the plant. Engineers must be present at the site for inspection of any incidents. The aging of the construction and the facilities must be watched and monitored. When Sariyar Dam was constructed, it was the only facility on the river. Gökçekaya Dam was constructed in 1972 and Yenice Dam was constituted in 2000 on the same river. Both facilities were downstream from Sariyar, but currently there are 11 hydroelectric facilities on Sakarya River, with one of them (Karg1 Dam) upstream from Sariyar. All of these plants -and especially Karg1 Dam, built in 2009- must be observed closely for their effects on the river flow, in terms of their possible adverse impacts on Sariyar Dam. Regarding the dilemma of removing dams, currently there are not any considerations for loss of ecological habitat, but for the conservation of the plant, criteria of industrial heritage property 
of the facility must be scientifically specified; the historical and cultural value must be publicized and propagated. For any upgrading of the plant, special care must be taken for the conservation and maintenance of the original elements and equipment.
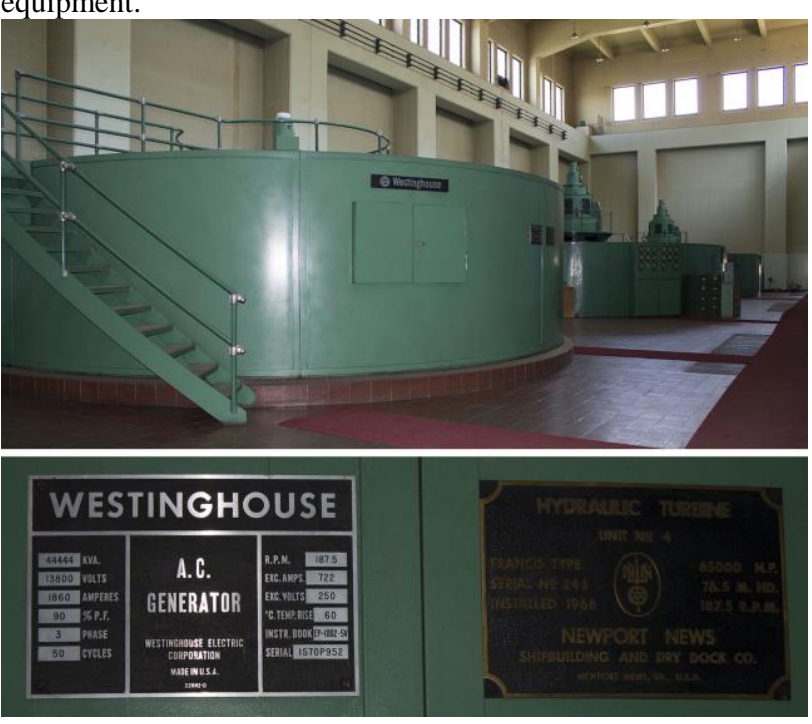

Figure 7. Sarıyar Hydroelectric Plant, turbines

Currently, there is an atelier on site, maintaining and repairing the original electrical equipment. Through this atelier, the monitored and controlled change of the plant is provided. An equilibrium is required between "conservation" and "interventions for safety measures and technological upgrading" of such structures. Within the controlled upgrading and changing of hydroelectric plants, the cultural properties and values of such buildings and equipment should also be regarded. Authentic and original components and elements of such facilities should be preserved / used as long as possible. When it is not possible / sustainable to continue using them, they should be kept in the vicinity of the facility, open to the appreciation of the public. In case of any intervention to Sarıyar Dam and Hydroelectric Plant, an interdisciplinary work of engineers, ecologists and heritage conservators must be provided for the conservation of the facility as an integral element of industrial heritage for the appreciation of future generations.

\section{ACKNOWLEDGEMENTS}

This study is sponsored and supported by TÜBİTAK (The Scientific \& Technological Research Council of Turkey.

\section{REFERENCES}

Alba M., Fregonese L., Prandi F., Scaioni M., Valgoi P., 2006. Structural Monitoring of a Large Dam by Terrestrial Laser Scanning. International Archives of Photogrammetry, Remote Sensing and Spatial Information Sciences, 36:5.

Agostinho, C. S., Pereira, C. R., Oliveira, R. J, Freitas, I. S., Marques, E. E., 2007. Movements Through a Fish Ladder: Temporal Patterns and Motivations to Move Upstream. Neotropical Ichthyology, vol.5 no.2, http://dx.doi.org/ 10.1590/S1679-62252007000200010.

Antova, G., 2015. Terrestrial Laser Scanning for Dam Deformation Monitoring - Case Study, FIG Working Week 2015, Sofia, Bulgaria.
Baykara, S., 1955. Electrification in Turkey. Railway, issue: 4849-50, September - October - November 1955. (in Turkish captions and titles translated by the researcher).

BCHYDRO, 2019. Upgrading of Ruskin Dam, Website of BCHydro, https://www.bchydro. com/energy-inbc/projects /Ruskin_dam_powerhouse_upgrade. html, retrieved on 06.03.2019.

Bellmore, J.R., Pess, G.R., Duda, J.J., O’Connor, J. E., East, A.E., Foley, M. M., Wilcox, A.C., Major, J.J., Shafroth, P.B., Morley, S.A., Magirl, C.S., Anderson, C.W., Evans, J.E., Torgersen, C.E., Craig, L.S., 2019. Conceptualizing Ecological Responses to Dam Removal: If You Remove It, What's to Come? BioScience, Volume 69, Issue 1, 1 January 2019, Pages 26-39,https://doi.org/10.1093/biosci/biy152.

Bosa, S., Petti, M., 2011. Shallow Water Numerical Model of the Wave Generated by the Vajont Landslide, Environmental Modelling \& Software, 2011, 406-418.

Bowles D. S., 2018. Safety and Risk Analysis, Twenty-sixth International Congress on Large Dams, edited by CIGB ICOLD, CRC Press.

Charlwood, R. G., 2009. Predicting the Long Term Behaviour and Service Life of Concrete Dams, in Long Term Behaviour of Dams, LTBD09: Proceedings of the 2nd International Conference 12-13 October 2009, Graz, Austria edited by E. Bauer, S. Semprich, G. Zenz.

Dağaşan, N., 1963. Electrification of Villages in Turkey. Electrical Engineering, issue: 73-74, p. 45-66. (in Turkish captions and titles translated by the researcher).

Erdem, S., 1963. A Short Review on the Application and Areas of Usage of Electricity in Turkey. Electrical Engineering, issue: 73-74, p. 83-85. (in Turkish -captions and titles translated by the researcher).

FERC (Federal Energy Regulatory Commission), 2018. Engineering Guidelines for the Evaluation of Hydropower Projects, Updated: March 14, 2018 URL: https://www.ferc.gov /industries/hydropower/safety/guidelines/eng-guide/chap3.asp? $c s r t=18183188277528160995]$, retrieved on on 06.01.2019.

Germaine, M. and Lespez, L., 2017. The Failure of the Largest Project to Dismantle Hydroelectric Dams in Europe? (Sélune River, France, 2009-2017). Water Alternatives 10(3): 655-676.

Guan, M., Ahilan, S., Yu, D., Peng, Y., Wright, N., 2018. Numerical Modelling of Hydro-morphological Processes Dominated by Fine Suspended Sediment in a Stormwater Pond, Journal of Hydrology, 556 (2018) 87-99.

ICOLD, 2018. Twenty-sixth International Congress on Large Dams, edited by CIGB ICOLD, CRC Press.

Jokilehto, J., 2011. A History of Architectural Conservation, Routledge, New York, USA.

Luino, F., Tosatti, G., Bonaria, V., 2014. Dam Failures in the 20th Century: Nearly 1,000 Avoidable Victims in Italy Alone. Journal of Environmental Science and Engineering, Vol. 3, No. 1: 19-31 ISSN 1934-8932. 
McClain, S., Lindloff, S., Baer, K., 2008. Dam Removal and Historic Preservation / Reconciling Dual Objectives, Report for American Rivers, Washington, USA.

National Park Service, 1996. Final Environmental Impact Statement(EIS) on Elwha River Ecosystem Restoration Implementation, November 1996, URL: https://www.nps.gov/ olym/learn/nature/loader.cfm?csModule=security/getfile\&PageI $\mathrm{D}=136253$, retrieved on 03.03.2019.

Ollikainen, R., 2011. Elwha Dam's days numbered; powerhouse first to be shut down. Peninsula Daily News, Monday, May 9, 2011, URL: http://www.peninsuladailynews.com/news/elwhadams-days-numbered-powerhouse-first-to-be-shut-downgallery/ retrieved on 03.03.2019.

Paronuzzi, P., Rigo, E., Bolla, A., 2013. Influence of FillingDrawdown Cycles of the Vajont Reservoir on Mt. Toc Slope Stability, Geomorphology, 191 (2013) 75 - 93.

Pilotti, M., Maranzoni, A., Tomirotti, M., Valerio, G., 2011. 1923 Gleno Dam Break: Case Study and Numerical Modeling. Journal of Hydraulic Engineering, 137(4) - April 2011 DOI: 10.1061/(ASCE)HY.1943-7900.0000327.

Rodriguez, J., 2012. Hydropower Landscapes and Tourism Development in the Pyrenees. Journal of Alpine Research, 1002, DOI: $10.400 /$ RGA.1819.

RUNOUT (2000). Major risk from rapid, large-volume landslides in Europe: The design and testing of new techniques for hazard assessment and mitigation. Final Report, EUROPEAN COMMISSION Programme Environment and Climate 1994-1998 ENV4-CT97-0527.

Schneider, D., 2006. Terrestrial Laser Scanning for Area Based Deformation Analysis of Towers and Water Dams. In: Proc. of 3rd IAG/12th FIG Symp., Baden, Austria, May 22-24,2006.

Slunga, E., 2001. Concept and Bases of Risk Analysis for Dams /With an Example Application on Kyrkösjärvi Dam. RESCDAM-project Development of Rescue Actions Based on Dam-Break Flood Analysis. URL:///C:/Users/asus/Downloads /RESCDAM_appendix3\%20(1).pdf.

Soderberg, L., 1986. Elwha Hydroelectric Power Plant National Register of Historic Places Nomination Form, Olympia, Wash.: Washington State Department of Archeology and Historic Preservation, 23 October 1986.

Suneel, S., 2018. Sedimentation Impact on Reservoirs and its Modelling Management Studies, Twenty-sixth International Congress on Large Dams edited by CIGB ICOLD, 2018.

Tschirschwitz, F., Mechelke K., Jansch, H., Kersten, P., 2016. Monitoring and Deformation Analysis of Groynes Using TLS at the River Elbe. The International Archives of the Photogrammetry, Remote Sensing and Spatial Information Sciences, volume XLI-B5, 2016 XXIII ISPRS Congress, 12-19 July 2016, Prague, Czech Republic.

Vacondio, R., Mignosa, P., Pagani, S., 2013. 3D SPH Numerical Simulation of the Wave Generated by the Vajont Rockslide, Advances in Water Resources, 59 (2013) 146 - 156.
Ward, L. 2005. Photo of Elwha Dam. Lower Elwha Fisheries Office (2005). 